\title{
Size/Layout Optimization of Truss Structures Using Shuffled Shepherd Optimization Method
}

\author{
Ali Kaveh ${ }^{1 *}$, Ataollah Zaerreza1 \\ 1 School of Civil Engineering, Iran University of Science and Technology, Narmak, Tehran, Postal Code 16846-13114, Iran \\ * Corresponding author, e-mail: alikaveh@iust.ac.ir
}

Received: 10 February 2020, Accepted: 21 February 2021, Published online: 19 March 2020

\begin{abstract}
The main purpose of this paper is to investigate the ability of the recently developed multi-community meta-heuristic optimization algorithm, shuffled shepherd optimization algorithm (SSOA), in layout optimization of truss structures. The SSOA is inspired by mimicking the behavior of shepherd in nature. In this algorithm, agents are first divided into communities which are called herd and then optimization process, inspired by the shepherd's behavior in nature, is operated on each community. The new position of agents is obtained using elitism technique. Then communities are merged for sharing the information. The results of SSOA in layout optimization show that SSOA is competitive with other considered meta-heuristic algorithms.
\end{abstract}

Keywords

meta-heuristic algorithms, shuffled shepherd optimization algorithm, size/layout optimization, truss structures

\section{Introduction}

Structural optimization is one of the most important field in engineers which has attracted a great deal of attention. Structural optimization can be divided into three categories: (1) size optimization that obtains optimal cross-sections for the structural members; (2) size/layout optimization which finds the optimal form for the structure and cross-sections of the structural members; (3) topology optimization that seeks optimal cross-sections and connectivity between structural members. In layout optimization both sizing and configuration optimization variables are involved and these optimize the material usage leading to economical design of truss structures.

Layout optimization has been investigated by different researchers using different methods. For example Wu and Chow [1] used GA for discrete variables for sections and continuous variables for nodal coordinates, Hasançebi and Erbatur [2] proposed an improved GA by combining the GA with annealing perturbation and adaptive design space reduction strategies, Kaveh and Khayatazad [3] developed the ray optimization, Kaveh and Laknejadi [4] presented a hybrid evolutionary graph based multi-objective algorithm, Kaveh and Zolghadr [5] suggested the democratic PSO, Kaveh et al. [6] presented hybrid PSO and SSO algorithm, Kaveh and Ilchi Ghazaan [7] utilized improved ray optimization, Kaveh and Mahjoubi [8] proposed an improved spiral optimization algorithm for layout optimization of truss structures with frequency constraints, Kazemzadeh Azad et al. [9] utilized big bang-big crunch for layout optimization of truss under dynamic excitation, and Kaveh et al. [10] suggested a modified dolphin monitoring operator for layout optimization of planar braced frames.

Meta-heuristic algorithms can be categorized considering different views $[11,12]$. The meta-heuristic algorithms can be categorized based on having one or more communities. As an example, particle swarm optimization (PSO) [13], bat algorithm (BA) [14], cuckoo search algorithm (CS) [15] slap swarm algorithm (SSA) [16], adaptive dimensional search (ADS) [17] and improved ray optimization algorithm (IRO) [18] are single community algorithms, while Shuffled Complex Evolution (SCE) [19], Shuffled Frog-leaping Algorithm (SFLA) [20], improved particle swarm optimization (IPSO) [21], Shuffled artificial bee colony algorithm (Shuffled-ABC) [22] are multi-community optimization algorithms.

As newly developed type of multi-community metaheuristic algorithm, the shuffled shepherd optimization algorithm (SSOA) is introduced for design of structural 
optimization problem by Kaveh and Zaerreza [23]. This algorithm can be considered as multi-community and multiagent method, where each community is called a herd and agent is a sheep. Each sheep when selected is called shepherd and move to new position

This paper considers: (i) The SSOA is introduced for optimization of layout problems. (ii) A comprehensive study of layout optimization for truss structures is presented. Some examples are chosen from the literature to verify the effectiveness of the algorithm. These examples are as follows: a 15 -member planar truss with 23 design variables, an 18-member planar truss with 12 design variables, A 25 -member spatial truss with 13 design variables, 47-member planar truss with 44 design variables, and a large-scale 272-member transmission tower with 72 design variables. The results show that the SSOA is very competitive with other methods in finding best solution.

The present paper is organized as follows: In Section 2 the SSOA is briefly described. In Section 3 four layout optimization of truss structures and a large-scale transmission tower are optimized utilizing the SSOA, and finally conclusions are derived in Section 4.

\section{Shuffled shepherd optimization algorithm}

The main objective of this section is to extend the application of the recently developed meta-heuristic algorithm called SSOA [23]. In SSOA, each solution candidate $X_{i}$ containing a number of variables (i.e. $X_{i}=\left\{X_{i, j}\right\}$ ) are considered as sheep. Each sheep is arranged by its objective function value, and then divided into herds. In each herd the sheep are selected in order, selected sheep are called shepherd and sheep with better objective function in a herd are called horses. Therefore, there are some horses and sheep for each shepherd. A shepherd tries to guide the sheep to the horse, the new position of the shepherd is achieved by moving to one of the sheep and horse. This is done for two purposes: (i) moving to worse agent causes exploration; (ii) and moving to a better member results in exploitation. New position of shepherd update when new objective function is not worse than old objective function, this leads to an elitism in the algorithm.

The SSOA procedure can briefly be outlined as follows:

1) The SSOA parameters $\alpha_{0}, \beta_{0}, \beta_{\max }$, iter ${ }_{\max }, h, s$ are set.

Where iter $_{\text {max }}$ is a maximum iteration number, ' $h$ ' is the number of herds; and ' $s$ ' is the number of sheep in each herd.

2) The initial position of the $i$ th sheep is determined randomly in an $m$-dimensional search space by the following equation (Eq. (1)):
$X_{i}^{0}=X_{\min }+\operatorname{rand} \circ\left(X_{\max }-X_{\min }\right) \quad i=1,2, \ldots, n$,

where $X_{i}^{0}$ is the initial solution vector of the $i$ th sheep, $X_{\max }$ and $X_{\min }$ are the bound of design variables, rand is a random vector with each component being in the interval $[0,1]$, and the number of components are equal to the number of variables, $n$ is the number of sheep ( $n$ is equal to $h \times s$ ) and sign 'o' denotes element-by-element multiplication.

3) The value of the objective function for each sheep is evaluated and sorted by their objective function in an ascending order. To build the herds, spread the sheep to the herd. The first $h$ sheep are selected and put randomly in each herd (put one sheep in each herd). Then select the second $\mathrm{h}$ sheep and put them in a herd again. This process is continued until all sheep are assigned into herd.

4) Select each sheep on a herd form first to the last one. Selected sheep is shepherd, sheep in herd better than shepherd is called horses. Select randomly one of the horses and the sheep; step size for each shepherd is calculated by

Stepsize $_{i}=\beta \times \operatorname{rand} \circ\left(X_{d}-X_{i}\right)+\alpha \times \operatorname{rand} \circ\left(X_{j}-X_{i}\right)$,

where $X_{i}, X_{d}, X_{j}$ are solution vectors of the shepherd, selected horse and selected sheep in an $m$-dimensional search space, respectively; rand is a random vector which each component is in interval $[0,1]$ and we have the number of components based on the number of components of solution vectors; $\alpha$ and $\beta$ calculate by Eq. (3) and Eq. (4), respectively.

$\propto=\alpha_{0}-\frac{\alpha_{0}}{\text { iter }_{\max }} \times$ iteration

$\beta=\beta_{0}+\frac{\beta_{\max }-\beta_{0}}{\text { iter }_{\text {max }}} \times$ iteration

First sheep selected in herd does not have better than itself so the first term of the step size is zero; and for the last sheep selected in herd which does not have worse than itself, the second term of the step size is zero.

5) The temple solution vector for each sheep calculate by the following equation (Eq. (5)):

$X_{i}^{\text {temple }}=X_{i}^{\text {old }}+$ stepsize $_{i}$.

If temple objective function is not worse than old objective function, then the position of the sheep is changed, so we have $X_{i}^{\text {new }}=X_{i}^{\text {temple }}$, otherwise the position of the shepherd is not changed and we have $X_{i}^{\text {new }}=X_{i}^{\text {old }}$. After position of the all sheep is updated merged the herds for sharing information. 
6) The optimization is repeated from step 3 until a termination criterion, specified as the maximum number of iterations, is satisfied

The pseudo-code of the SSOA is presented in Algorithm 1

\section{Numerical examples}

The ability of the SSOA is tested using five layout optimization problems. Four of these problems include discrete sizing variables and continuous configuration variables, and in the last example sizing and configuration variables are continuous. Parameter settings of the SSOA and the number of iteration limits on numeric examples are listed in Table 1.

\subsection{The 15-bar planar truss structure}

The first layout optimization problem is the 15-bar planar truss subjected to traversal load of 10 kip as shown in Fig. 1. The optimization problem includes 15 discrete

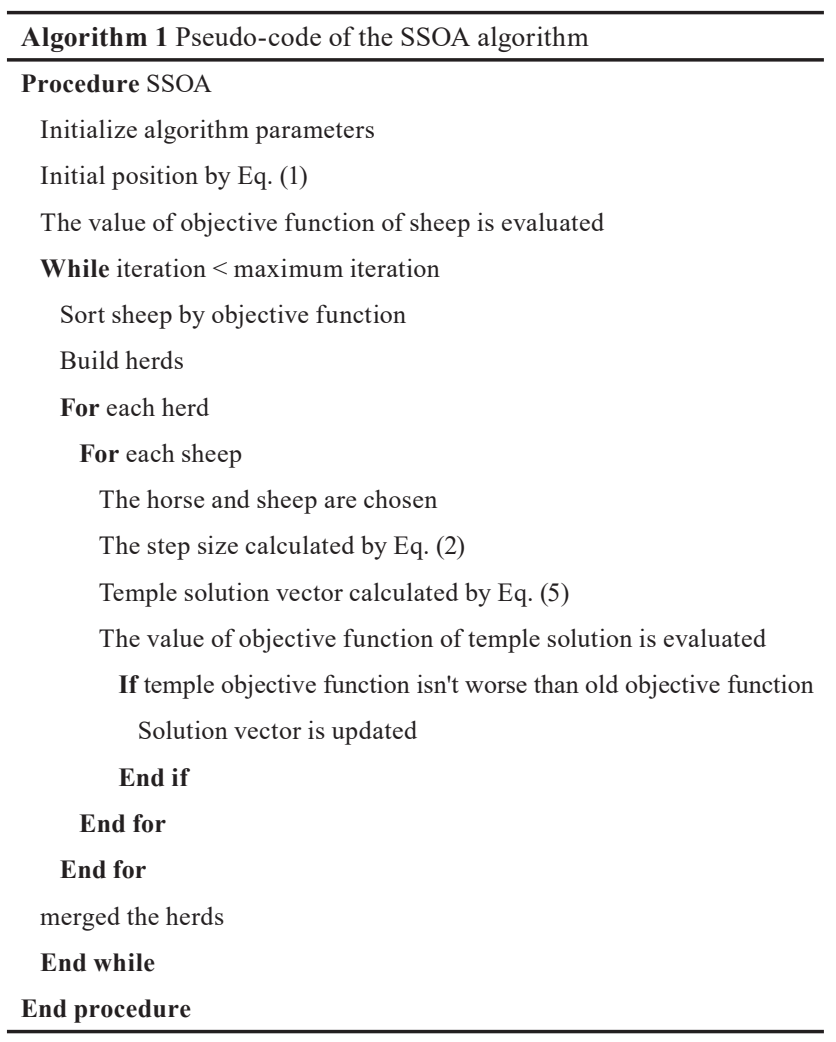

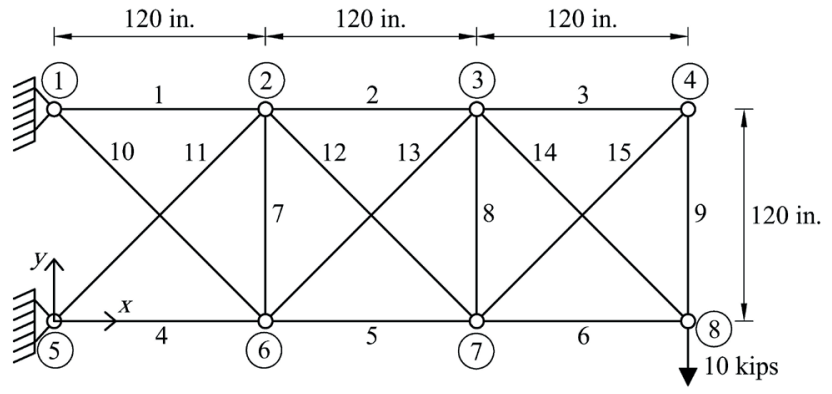

Fig. 1 Schematic of the 15-bar planar truss

sizing variables for the cross-section areas and 8 continuous layout variables for nodal coordinates. All members are subjected to stress limitation of $\pm 25 \mathrm{ksi}$. Optimization variables and input data of the truss are given in Table 2 .

Table 3 shows that the SSOA finds the optimal solution with the least number of analyses compared to the other algorithm. Average and standard deviation of the SSOA for 30 independent runs are $78.3675(\mathrm{lb})$ and $3.0373(\mathrm{lb})$, respectively. Best solution for this problem is 72.5152 that has been found by Kazemzadeh Azad and Jayant Kulkarni [24] but average of 50 independent runs is 79.49 that is more than that of the SSOA. Fig. 2 shows the best

Table 2 Simulation data for the 15-bar planar truss

\begin{tabular}{cc}
\hline Sizing variables & Layout variables \\
\hline$A_{i}, i=1,2, \ldots, 15$ & $\mathrm{x}_{2}=\mathrm{x}_{6} ; \mathrm{x}_{3}=\mathrm{x}_{7} ; \mathrm{y}_{2} ; \mathrm{y}_{3} ; \mathrm{y}_{4} ; \mathrm{y}_{6} ; \mathrm{y}_{7} ; \mathrm{y}_{8}$ \\
Possible sizing variables \\
\hline
\end{tabular}

$A_{i} \in S=\{0.111,0.141,0.174,0.220,0.270,0.287,0.347,0.440,0.539,0.954$, $1.081,1.174,1.333,1.488,1.764,2.142,2.697,2.800,3.131,3.565,3.813$, $4.805,5.952,6.572,7.192,8.525,9.300,10.850,13.330,14.290,17.170$, $19.180\}\left(i n^{2}\right)$

Layout variables bounds

100 in. $\leq x_{2} \leq 140$ in

220 in. $\leq x_{3} \leq 260$ in.;

100 in. $\leq y_{2} \leq 140$ in

100 in. $\leq y_{3} \leq 140$ in.

50 in. $\leq y_{4} \leq 90$ in.;

-20 in. $\leq y_{6} \leq 20$ in.;

-20 in. $\leq y_{7} \leq 20$ in.;

20 in. $\leq y_{8} \leq 60$ in.;

Young modulus $\mathrm{E}=10^{4}(\mathrm{ksi})$

Material density $\rho=0.1\left(\mathrm{lb} / \mathrm{in}^{3}\right)$

Table 1 Parameters setting and maximum iteration number for the SSOA

\begin{tabular}{|c|c|c|c|c|c|c|}
\hline Problem & $\propto_{0}$ & $\beta_{0}$ & $\beta_{\max }$ & Number of herds & Size of herds & Maximum iteration number \\
\hline 15-bar planar truss & 1.5 & 2 & 3 & 4 & 4 & 490 \\
\hline 18-bar planar truss & 0.6 & 2.3 & 2.5 & 4 & 4 & 599 \\
\hline 25-bar spatial truss & 0.5 & 2.4 & 2.6 & 4 & 4 & 300 \\
\hline 47-bar planer truss & 0.5 & 2 & 2.3 & 4 & 5 & 1.100 \\
\hline 272-bar transmission tower & 0.5 & 2.0 & 2.4 & 3 & 10 & 1.700 \\
\hline
\end{tabular}


Table 3 Optimum result for the 15-bar planar truss

\begin{tabular}{|c|c|c|c|c|c|c|c|}
\hline \multirow{2}{*}{$\begin{array}{l}\text { Design } \\
\text { variables }\end{array}$} & \multirow{2}{*}{$\begin{array}{c}\text { Tang et al. } \\
{[25]}\end{array}$} & \multirow{2}{*}{$\begin{array}{c}\text { Rahami et al. } \\
\text { [26] }\end{array}$} & \multirow{2}{*}{$\begin{array}{c}\text { Kazemzadeh Azad et } \\
\text { al. [24] }\end{array}$} & \multirow{2}{*}{$\begin{array}{l}\text { Miguel et al. [27] } \\
\text { FA }\end{array}$} & \multicolumn{2}{|c|}{ Ho-Huu et al. [28] } & \multirow{2}{*}{$\begin{array}{c}\text { Present work } \\
\text { SSOA }\end{array}$} \\
\hline & & & & & R-ICDE & D-ICDE & \\
\hline $\mathrm{A}_{1}$ & 1.081 & 1.081 & 0.954 & 0.954 & 1.081 & 1.081 & 0.954 \\
\hline $\mathrm{A}_{2}$ & 0.539 & 0.539 & 0.539 & 0.539 & 0.539 & 0.539 & 0.539 \\
\hline $\mathrm{A}_{3}$ & 0.287 & 0.287 & 0.111 & 0.220 & 0.270 & 0.141 & 0.111 \\
\hline $\mathrm{A}_{4}$ & 0.954 & 0.954 & 0.954 & 0.954 & 0.954 & 0.95 & 0.954 \\
\hline $\mathrm{A}_{5}$ & 0.954 & 0.539 & 0.539 & 0.539 & 0.954 & 0.539 & 0.539 \\
\hline $\mathrm{A}_{6}$ & 0.220 & 0.141 & 0.347 & 0.22 & 0.22 & 0.287 & 0.347 \\
\hline $\mathrm{A}_{7}$ & 0.111 & 0.111 & 0.111 & 0.111 & 0.111 & 0.111 & 0.111 \\
\hline $\mathrm{A}_{8}$ & 0.111 & 0.111 & 0.111 & 0.111 & 0.111 & 0.111 & 0.111 \\
\hline $\mathrm{A}_{9}$ & 0.287 & 0.539 & 0.111 & 0.287 & 0287 & 0.141 & 0.174 \\
\hline $\mathrm{A}_{10}$ & 0.220 & 0.440 & 0.44 & 0.440 & 0.22 & 0.347 & 0.44 \\
\hline $\mathrm{A}_{11}$ & 0.440 & 0.539 & 0.44 & 0.440 & 0.44 & 0.44 & 0.44 \\
\hline $\mathrm{A}_{12}$ & 0.440 & 0.270 & 0.174 & 0.220 & 0.44 & 0.27 & 0.174 \\
\hline $\mathrm{A}_{13}$ & 0.111 & 0.220 & 0.174 & 0.220 & 0.174 & 0.27 & 0.174 \\
\hline $\mathrm{A}_{14}$ & 0.220 & 0.141 & 0.347 & 0.270 & 0.174 & 0.287 & 0.347 \\
\hline $\mathrm{A}_{15}$ & 0.347 & 0.287 & 0.111 & 0.220 & 0.347 & 0.174 & 0.111 \\
\hline $\mathrm{x}_{2}$ & 133.612 & 101.5775 & 105.7835 & 114.967 & 117.4983 & 100.0309 & 111.2513 \\
\hline $\mathrm{x}_{3}$ & 234.752 & 227.9112 & 258.5965 & 247.040 & 242.9729 & 238.7010 & 248.7576 \\
\hline $\mathrm{y}_{2}$ & 100.449 & 134.7986 & 133.6284 & 125.919 & 112.3731 & 132.8471 & 132.8862 \\
\hline $\mathrm{y}_{3}$ & 104.738 & 128.2206 & 105.0023 & 111.067 & 101.2684 & 125.3669 & 109.3964 \\
\hline $\mathrm{y}_{4}$ & 73.762 & 54.8630 & 54.4546 & 58.298 & 54.6397 & 60.3072 & 55.1655 \\
\hline $\mathrm{y}_{6}$ & -10.067 & -16.4484 & -19.929 & -17.564 & -12.3953 & -10.6651 & -19.5015 \\
\hline $\mathrm{y}_{7}$ & -1.339 & -13.3007 & 3.6223 & -5.821 & -14.3909 & -12.2457 & 10.1465 \\
\hline $\mathrm{y}_{8}$ & 50.402 & 54.8572 & 54.4474 & 31.465 & 54.6396 & 59.9931 & 52.1898 \\
\hline Weight (lb) & 79.820 & 76.6854 & 72.5152 & 75.55 & 80.5688 & 74.6818 & 72.8615 \\
\hline No. of analyses & 8,000 & 8,000 & 10,000 & 8,000 & 7,980 & 7,980 & 7,856 \\
\hline
\end{tabular}

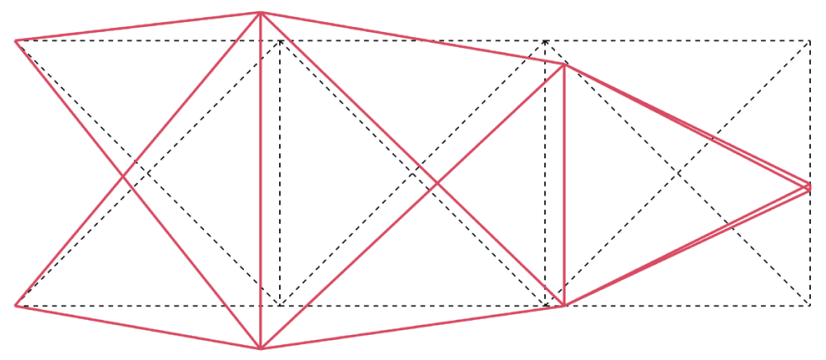

Fig. 2 Comparison of optimized layout for the 15-bar planar truss

shape of the 15-bar planar truss find by the present work. Fig. 3 shows the convergence histories of the best result and the mean performance of 30 independent runs for the 15-bar planar truss.

\subsection{The 18-bar planar truss structure}

For the 18-bar planar truss structure shown in Fig. 4, material density is $0.1 \mathrm{lb} / \mathrm{in}^{3}$ and the modulus of elasticity is $10,000 \mathrm{ksi}$. The members are subjected to the stress limit of $\pm 25 \mathrm{ksi}$ and Euler buckling stresses for compression member (the buckling strength of the ith element is set to

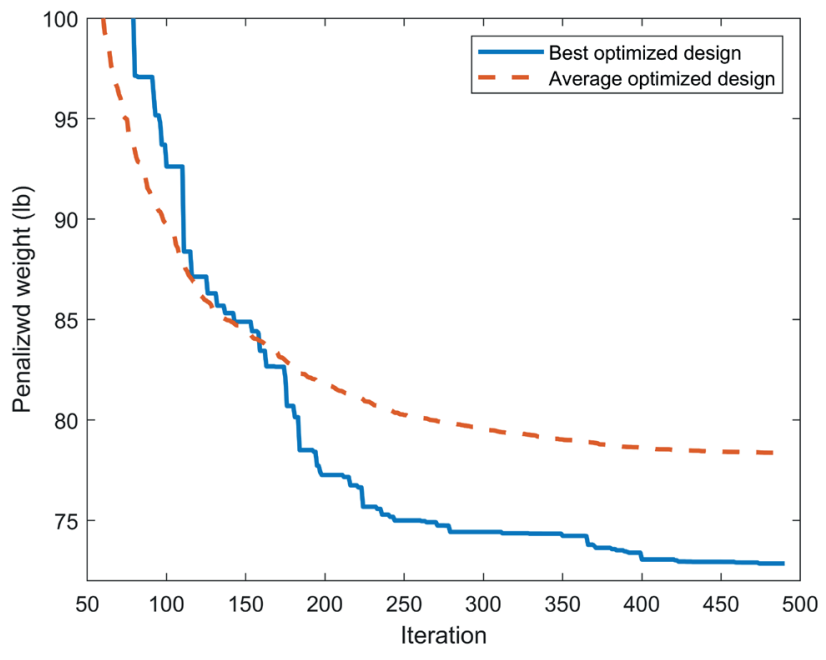

Fig. 3 Convergence histories of the optimization for the 15-bar planar truss

$\left.4 E A / L^{2}\right)$. Members are classified into four groups as follows: $\mathrm{A}_{1}=\mathrm{A}_{4}=\mathrm{A}_{8}=\mathrm{A}_{12}=\mathrm{A}_{16} ; \mathrm{A}_{2}=\mathrm{A}_{6}=\mathrm{A}_{10}=\mathrm{A}_{14}=\mathrm{A}_{18}$; $A_{3}=A_{7}=A_{11}=A_{15} ; A_{5}=A_{9}=A_{13}=A_{17}$. Hence there are four sizing variables for cross section areas which are chosen from following discrete set: 
$S=\{2.00,2.25,2.50, \ldots, 21.25,21.50,21.75\}\left(\mathrm{in}^{2}\right)$ and eight layout variables with the following bounds: 775 in. $\leq \mathrm{x} \_3 \leq 1225 \mathrm{in}$.

525 in. $\leq$ x $5 \leq 975$ in.

275 in. $\leq \mathrm{x}_{-} 7 \leq 725 \mathrm{in}$.

25 in. $\leq \mathrm{x} \_9 \leq 475$ in.

-225 in. $\leq \mathrm{y}_{3}, \mathrm{y}_{5}, \mathrm{y}_{7}, \mathrm{y}_{9} \leq 245$ in.

Table 4 presents the optimum designs obtained by the other methods and SSOA. It can be seen that SSOA has found a smaller weight compared to those of Hasançebi and Erbatur [29], Kaveh and Kalatjari [30], Rahami et al. [26] and Ho-Huu et al. [28] but with higher number of analyses than them and found higher weight than Kazemzadeh Azad et al. [24] but with smaller number of analyses, and the average and standard deviation of SSOA for 40 independent runs are 4768.5 (lb) and 474.10 (lb), respectively. Optimum layout found by SSOA is shown in Fig. 5. The convergence curves for the best result and the mean performance of 40 independent runs for the 18-bar planar truss are shown in Fig. 6.

\subsection{The 25-bar spatial truss}

The third layout optimization problem is the 25-bar spatial truss as shown in Fig. 7. The optimization problem includes 13 design variables containing 8 discrete sizing variables for the cross-section areas and 5 continuous layout variables for nodal coordinate. All members are subjected to stress limitation of $\pm 40 \mathrm{ksi}$ and all nodal displacement in all directions is limited to \pm 0.3 in. Optimization variables and input data of this truss are provided in Table 5.

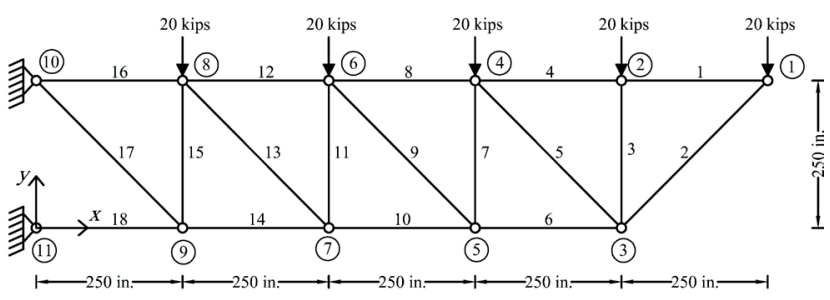

Fig. 4 Schematic of the 18-bar planar truss

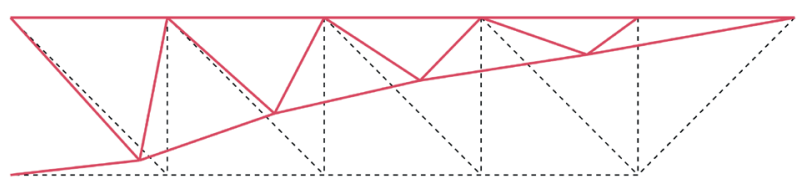

Fig. 5 Comparison of optimized layout for the 18-bar planar truss

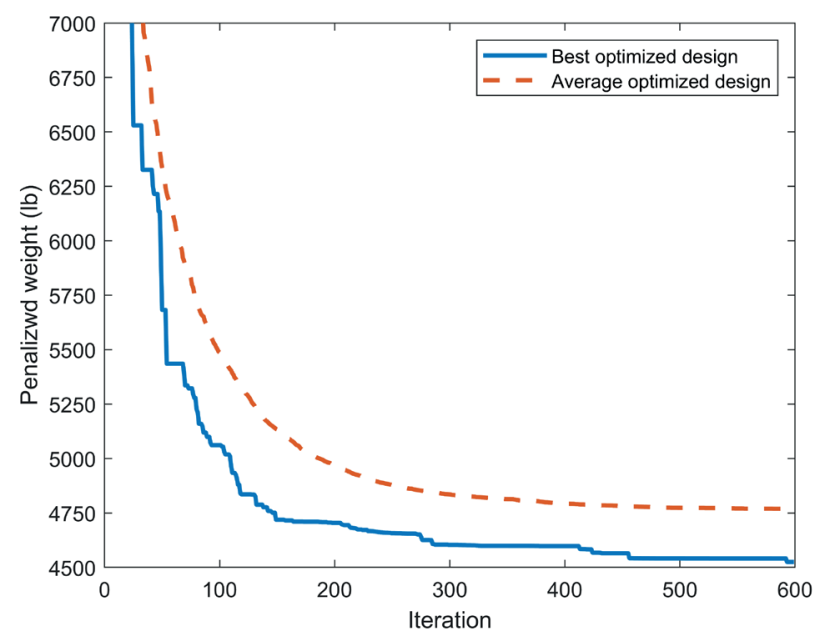

Fig. 6 Convergence histories of the optimization for the 18-bar planar truss

Table 4 Optimum result for the 18-bar planar truss

\begin{tabular}{|c|c|c|c|c|c|c|c|}
\hline \multirow{2}{*}{$\begin{array}{l}\text { Design } \\
\text { variables }\end{array}$} & \multirow{2}{*}{$\begin{array}{l}\text { Hasançebi and } \\
\text { Erbatur [29] }\end{array}$} & \multirow{2}{*}{$\begin{array}{l}\text { Kaveh and } \\
\text { Kalatjari [30] }\end{array}$} & \multirow{2}{*}{$\begin{array}{c}\text { Rahami et al. } \\
{[26]}\end{array}$} & \multirow{2}{*}{$\begin{array}{c}\text { Kazemzadeh Azad et } \\
\text { al. [24] }\end{array}$} & \multicolumn{2}{|c|}{ Ho-Huu et al. [28] } & \multirow{2}{*}{$\begin{array}{c}\text { Present work } \\
\text { SSOA }\end{array}$} \\
\hline & & & & & R-ICDE & D-ICDE & \\
\hline $\mathrm{A}_{1}$ & 12.5 & 12.25 & 12.75 & 12.75 & 12.25 & 13 & 12 \\
\hline $\mathrm{A}_{2}$ & 18.25 & 18 & 18.50 & 18.25 & 18 & 17.5 & 18 \\
\hline $\mathrm{A}_{3}$ & 5.50 & 5.25 & 4.75 & 5 & 5.5 & 6.5 & 5 \\
\hline $\mathrm{A}_{5}$ & 3.75 & 4.25 & 3.25 & 3.25 & 4.5 & 3 & 4.5 \\
\hline $\mathrm{x}_{3}$ & 933 & 913 & 917.4775 & 916.0812 & 909.52 & 914.06 & 918.8398 \\
\hline $\mathrm{y}_{3}$ & 188 & 186.8 & 193.7899 & 191.4300 & 184.02 & 183.06 & 191.2096 \\
\hline $\mathrm{x}_{5}$ & 658 & 650 & 654.3243 & 650.0573 & 646.71 & 640.53 & 652.8561 \\
\hline $\mathrm{y}_{5}$ & 148 & 150.5 & 159.9436 & 153.4968 & 147.73 & 133.74 & 150.1858 \\
\hline$x_{7}$ & 422 & 418.8 & 424.4821 & 419.4508 & 416.45 & 406.12 & 420.8011 \\
\hline $\mathrm{y}_{7}$ & 100 & 97.40 & 108.5779 & 105.5322 & 96.46 & 92.63 & 97.6796 \\
\hline $\mathrm{x}_{9}$ & 205 & 204.8 & 208.4691 & 205.6591 & 204.03 & 196.69 & 205.7989 \\
\hline $\mathrm{y}_{9}$ & 32 & 26.70 & 37.6349 & 36.4848 & 25.32 & 37.06 & 23.2213 \\
\hline Weight (lb) & 4574.28 & 4547.9 & 4530.68 & 4520.2 & 4591.42 & 4554.29 & 4524.94 \\
\hline No. of analyses & N/A & N/A & 8,000 & 10,000 & 8,025 & 8,025 & 9,600 \\
\hline
\end{tabular}


Table 5 Simulation data for the 25-bar spatial truss

\begin{tabular}{|c|c|c|c|}
\hline \multicolumn{4}{|c|}{ Sizing variables } \\
\hline \multicolumn{4}{|c|}{$\mathrm{A} 1 ; \mathrm{A} 2=\mathrm{A} 3=\mathrm{A} 4=\mathrm{A} 5 ; \mathrm{A} 6=\mathrm{A} 7=\mathrm{A} 8=\mathrm{A} 9 ; \mathrm{A} 10=\mathrm{A} 11 ; \mathrm{A} 12=\mathrm{A} 13$} \\
\hline \multicolumn{4}{|c|}{$\mathrm{A} 14=\mathrm{A} 15=\mathrm{A} 16=\mathrm{A} 17 ; \mathrm{A} 18=\mathrm{A} 19=\mathrm{A} 20=\mathrm{A} 21 ; \mathrm{A} 22=\mathrm{A} 23=\mathrm{A} 24=\mathrm{A} 25$} \\
\hline \multicolumn{4}{|c|}{ Layout variables } \\
\hline \multicolumn{4}{|c|}{$x_{4}=x_{5}=-x_{3}=-x_{6} ; x_{8}=x_{9}=-x_{7}=-x_{10}$} \\
\hline \multicolumn{4}{|c|}{$y_{3}=y_{4}=-y_{5}=-y_{6} ; y_{7}=y_{8}=-y_{9}=-y_{10}$} \\
\hline \multicolumn{4}{|c|}{$z_{3}=z_{4}=z_{5}=z_{6}$} \\
\hline \multicolumn{4}{|c|}{ Possible sizing variables } \\
\hline \multirow{2}{*}{\multicolumn{4}{|c|}{$\begin{array}{l}A_{i} \in S=\{0.1,0.2,0.3,0.4,0.5,0.6,0.7,0.8,0.9,1.0,1.1,1.2,1.3,1 \\
1.7,1.8,1.9,2.0,2.1,2.2,2.3,2.4,2.5,2.6,2.8,3.0,3.2,3.4\}\left(i^{2}\right)\end{array}$}} \\
\hline & & & \\
\hline \multicolumn{4}{|c|}{ Layout variables bounds } \\
\hline \multicolumn{4}{|c|}{20 in. $\leq \mathrm{x}_{4} \leq 60$ in.; } \\
\hline \multicolumn{4}{|c|}{40 in. $\leq \mathrm{x}_{8} \leq 80$ in.; } \\
\hline \multicolumn{4}{|c|}{40 in. $\leq \mathrm{y}_{4} \leq 80$ in.; } \\
\hline \multicolumn{4}{|c|}{100 in. $\leq \mathrm{y}_{8} \leq 140$ in } \\
\hline \multicolumn{4}{|c|}{90 in. $\leq \mathrm{z}_{4} \leq 130$ in. } \\
\hline \multicolumn{4}{|l|}{ Loads } \\
\hline nodes & $F_{x}(\mathrm{kips})$ & $F_{y}($ kips $)$ & $F_{z}$ (kips) \\
\hline 1 & 1.0 & -10 & -10 \\
\hline 2 & 0.0 & -10 & -10 \\
\hline 3 & 0.5 & 0.0 & 0.0 \\
\hline 6 & 0.6 & 0.0 & 0.0 \\
\hline \multicolumn{4}{|c|}{ Young modulus $E=10^{4}(\mathrm{ksi})$} \\
\hline Materi & $\rho=0.1(\mathrm{ll}$ & & \\
\hline
\end{tabular}

Table 6 shows that SSOA has found the best solution with the least number of analyses among the other algorithms. Average weight and standard deviation for 30 independent runs are $122.4073 \mathrm{lb}$ and $6.3443 \mathrm{lb}$, respectively. Optimum layout found by SSOA is shown in Fig. 8.

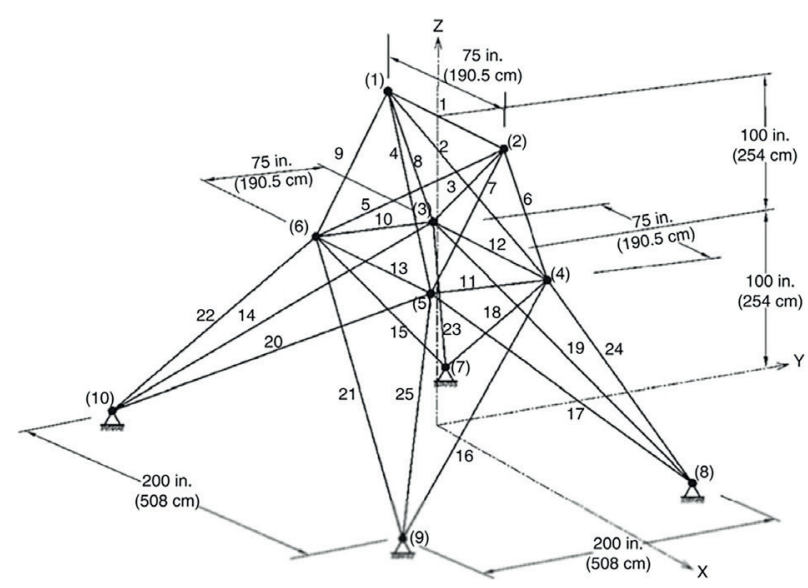

Fig. 7 Schematic of the 25-bar spatial truss
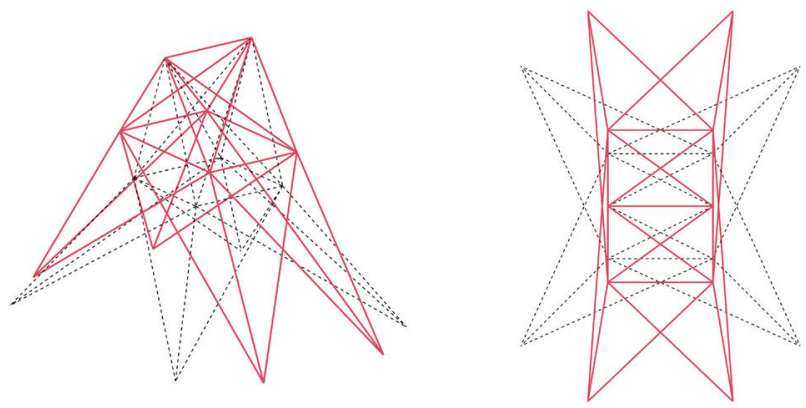

Fig. 8 Comparison of optimized layout for the 25-bar spatial truss

Table 6 Optimum result for the 25-bar spatial truss

\begin{tabular}{|c|c|c|c|c|c|c|c|}
\hline \multirow{2}{*}{$\begin{array}{l}\text { Design } \\
\text { variables }\end{array}$} & \multirow{2}{*}{ Wu and Chow [1] } & \multirow{2}{*}{$\begin{array}{c}\text { Kaveh and } \\
\text { Kalatjari [30] }\end{array}$} & \multirow{2}{*}{ Tang et al. [25] } & \multirow{2}{*}{$\begin{array}{c}\text { Rahami et al. } \\
{[26]}\end{array}$} & \multicolumn{2}{|c|}{ Ho-Huu et al. [28] } & \multirow{2}{*}{$\begin{array}{c}\text { Present work } \\
\text { SSOA }\end{array}$} \\
\hline & & & & & R-ICDE & D-ICDE & \\
\hline A1 & 0.1 & 0.1 & 0.1 & 0.1 & 0.2 & 0.1 & 0.1 \\
\hline A2 & 0.2 & 0.1 & 0.1 & 0.1 & 0.2 & 0.1 & 0.1 \\
\hline A6 & 1.1 & 1.1 & 1.1 & 1.1 & 0.9 & 0.9 & 1.0 \\
\hline A10 & 0.2 & 0.1 & 0.1 & 0.1 & 0.2 & 0.1 & 0.1 \\
\hline A12 & 0.3 & 0.1 & 0.1 & 0.1 & 0.2 & 0.1 & 0.1 \\
\hline A14 & 0.1 & 0.1 & 0.2 & 0.1 & 0.2 & 0.1 & 0.1 \\
\hline A18 & 0.2 & 0.1 & 0.2 & 0.2 & 0.2 & 0.1 & 0.1 \\
\hline A 22 & 0.9 & 1.0 & 0.7 & 0.8 & 1.0 & 1.0 & 0.9 \\
\hline$x 4$ & 41.07 & 36.23 & 35.47 & 33.0487 & 36.380 & 36.83 & 37.6762 \\
\hline y4 & 53.47 & 58.56 & 60.37 & 53.5663 & 57.080 & 58.53 & 54.4273 \\
\hline $\mathrm{z} 4$ & 124.6 & 115.59 & 129.07 & 129.9092 & 126.62 & 122.67 & 129.9991 \\
\hline $\mathrm{x} 8$ & 50.80 & 46.46 & 45.06 & 43.7826 & 48.200 & 49.21 & 51.9006 \\
\hline y8 & 131.48 & 127.95 & 137.06 & 136.8381 & 139.90 & 136.74 & 139.5535 \\
\hline Weight (lb) & 136.20 & 124.0 & 124.943 & 120.115 & 145.275 & 118.76 & 117.2591 \\
\hline No. of analyses & N/A & N/A & 6,000 & 10,000 & 6,000 & 6,000 & 4,816 \\
\hline
\end{tabular}




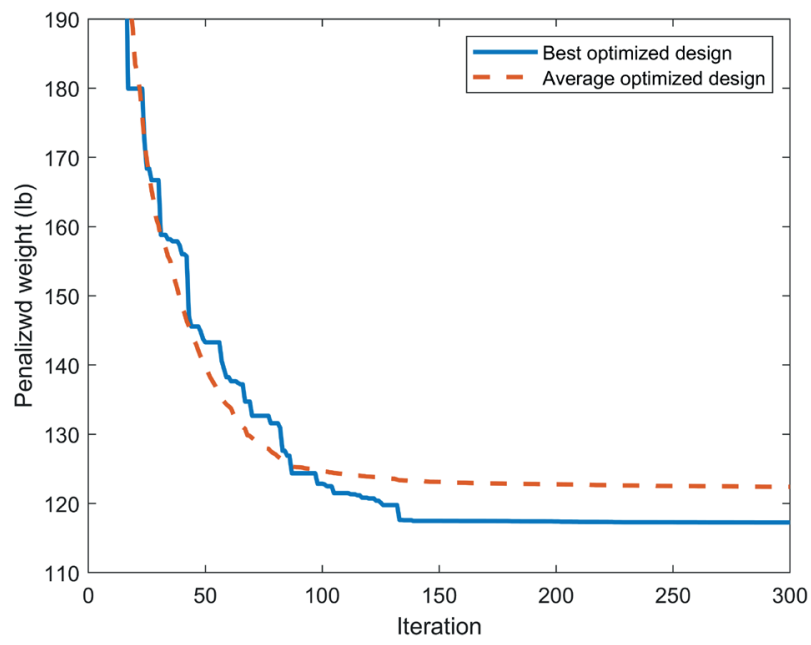

Fig. 9 Convergence histories of the optimization for the 25-bar spatial truss

Convergence curves for the best result and the mean performance of 30 independent runs for the 25-bar spatial truss are shown in Fig. 9.

\subsection{7-bar planer truss}

The 47-bar planer truss shown in Fig. 10 is optimized by different researchers for three load cases as shown in Table 7. The optimization problem includes 44 design variables containing 27 discrete sizing variables for the cross-section areas and 17 continuous layout variables for nodal coordinate. All members are subjected to stress limitation in tension and compression of $20 \mathrm{ksi}$ and $15 \mathrm{ksi}$, respectively. Euler buckling stresses for compression members (the buckling strength of the $i$ th element) is set to $3.96 E A / L^{2}$, and there is no limitation for nodes displacement. Optimization variables and input data of truss are given in Table 7.

Comparison of the optimal design by this work with optimum designs obtained by Salajegheh and Vanderplaats [31], Hasançebi and Erbatur [2, 29] and Panagant and Bureerat [32] is provided in Table 8. It can be seen that SSOA found the lightest weight $(1869.876 \mathrm{lb})$ in less number of analyses $(20,020)$, with average and standard deviation being $1929.91 \mathrm{lb}$ and $29.55 \mathrm{lb}$, respictivly. Optimum layout found by SSOA is shown in Fig 11. Fig. 12 shows the convergence curves for the best result and the mean performance of 30 independent runs for the 47-bar planar truss.

\subsection{The 272-bar transmission tower}

Last layout optimization problem is the optimization of 272-bar transmission tower shown in Fig. 13. The 272-bar transmission tower first time presented by Kaveh and

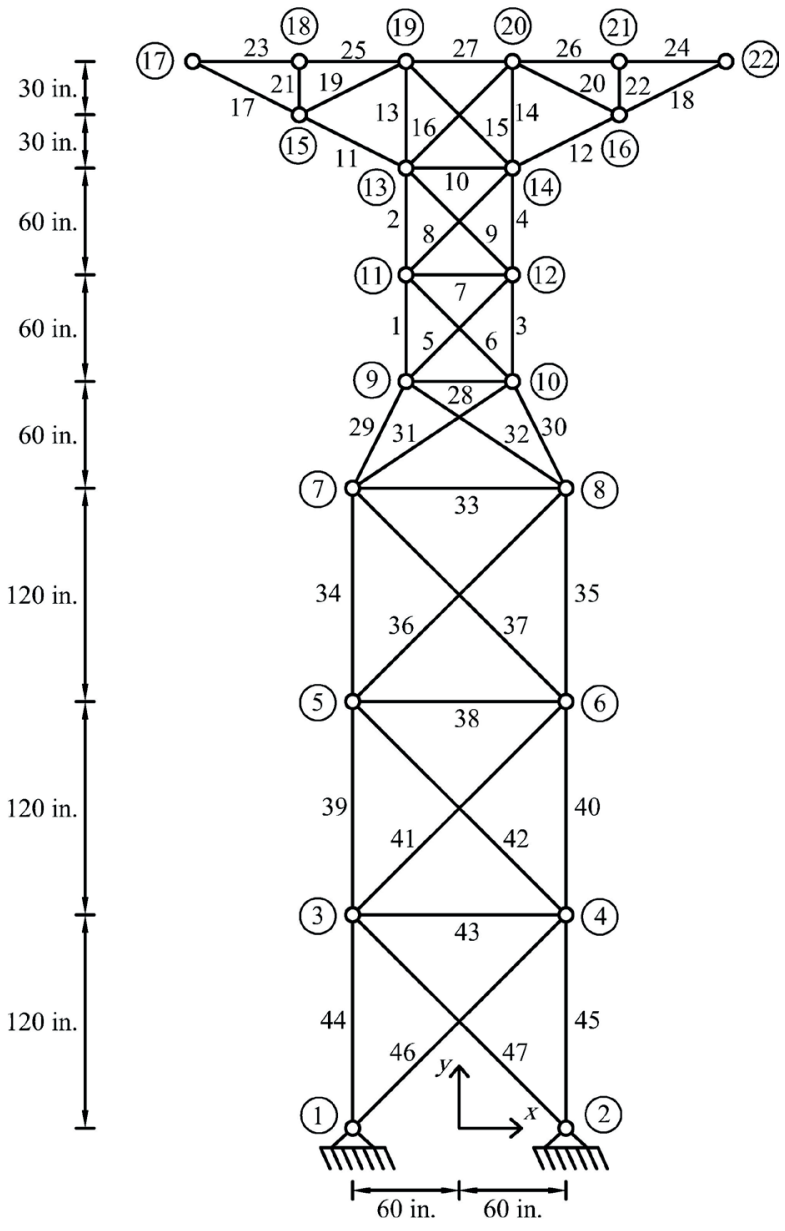

Fig. 10 Schematic of the 47-bar planar truss

Table 7 Simulation data for the 47-bar planar truss

\begin{tabular}{|c|c|c|c|}
\hline \multicolumn{4}{|c|}{ Sizing variables } \\
\hline \multicolumn{4}{|c|}{$\begin{array}{l}\mathrm{A}_{3}=\mathrm{A}_{1} ; \mathrm{A}_{4}=\mathrm{A}_{2} ; \mathrm{A}_{5}=\mathrm{A}_{6} ; \mathrm{A}_{1} ; \mathrm{A}_{8}=\mathrm{A}_{9} ; \mathrm{A}_{10} ; \mathrm{A}_{12}=\mathrm{A}_{11} ; \mathrm{A}_{14}=\mathrm{A}_{13} ; \\
\mathrm{A}_{15}=\mathrm{A}_{16} ; \mathrm{A}_{18}=\mathrm{A}_{17} ; \mathrm{A}_{20}=\mathrm{A}_{19} ; \mathrm{A}_{22}=\mathrm{A}_{21} ; \mathrm{A}_{24}=\mathrm{A}_{23} ; \mathrm{A}_{26}=\mathrm{A}_{25} ; \mathrm{A}_{27} ; \\
\mathrm{A}_{28} ; \mathrm{A}_{30}=\mathrm{A}_{29} ; \mathrm{A}_{31}=\mathrm{A}_{32} ; \mathrm{A}_{33} ; \mathrm{A}_{35}=\mathrm{A}_{34} ; \mathrm{A}_{36}=\mathrm{A}_{37} ; \mathrm{A}_{38} ; \mathrm{A}_{40}=\mathrm{A}_{39} ; \\
\mathrm{A}_{41}=\mathrm{A}_{42} ; \mathrm{A}_{43} ; \mathrm{A}_{45}=\mathrm{A}_{44} ; \mathrm{A}_{46}=\mathrm{A}_{47} \\
\text { Layout variables }\end{array}$} \\
\hline \multicolumn{4}{|c|}{$\begin{array}{l}x_{2}=-x_{1} ; x_{4}=-x_{3} ; y_{4}=y_{3} ; x_{6}=-x_{5} ; y_{6}= \\
x_{10}=-x_{9} ; y_{10}=y_{9} ; x_{12}=-x_{11} ; y_{12}=y_{11} ; x_{14} \\
x_{20}=-x_{19} ; y_{20}=y_{19} ; x_{21}=-x_{18} ; y_{21}=y_{18}\end{array}$} \\
\hline \multicolumn{4}{|c|}{ Possible sizing variables } \\
\hline \multicolumn{4}{|c|}{$A_{i} \in S=\{0.1,0.2,0.3,0.4, \ldots, 4.8,4.9,5.0\}\left(\mathrm{in}^{2}\right)$} \\
\hline \multicolumn{4}{|c|}{ Loads } \\
\hline case & Nodes & $F_{x}(\mathrm{kips})$ & $F_{y}(\mathrm{kips})$ \\
\hline \multirow[t]{2}{*}{1} & 17 & 6.0 & -14.0 \\
\hline & 22 & 6.0 & -14.0 \\
\hline 2 & 17 & 6.0 & -14.0 \\
\hline 3 & 22 & 6.0 & -14.0 \\
\hline \multicolumn{4}{|c|}{ Young modulus $E=3 \times 10^{4}(\mathrm{ksi})$} \\
\hline \multicolumn{4}{|c|}{ Material density $\rho=0.3\left(\mathrm{lb} / \mathrm{in}^{3}\right)$} \\
\hline
\end{tabular}


Table 8 Optimum result for the 47-bar planar truss

\begin{tabular}{|c|c|c|c|c|c|}
\hline Design variables & $\begin{array}{c}\text { Salajegheh and } \\
\text { Vanderplaats [29] }\end{array}$ & $\begin{array}{c}\text { Hasançebi and } \\
\text { Erbatur [2] }\end{array}$ & $\begin{array}{c}\text { Hasançebi and } \\
\text { Erbatur [25] }\end{array}$ & $\begin{array}{c}\text { Panagant and Bureerat } \\
{[30]}\end{array}$ & $\begin{array}{c}\text { Present work } \\
\text { SSOA }\end{array}$ \\
\hline $\mathrm{A}_{3}$ & 2.61 & 2.5 & 2.5 & 2.7 & 2.8 \\
\hline $\mathrm{A}_{4}$ & 2.56 & 2.2 & 2.5 & 2.6 & 2.5 \\
\hline $\mathrm{A}_{5}$ & 0.69 & 0.7 & 0.8 & 0.7 & 0.7 \\
\hline $\mathrm{A}_{7}$ & 0.47 & 0.1 & 0.1 & 0.1 & 0.1 \\
\hline $\mathrm{A}_{8}$ & 0.80 & 1.3 & 0.7 & 0.8 & 1.0 \\
\hline $\mathrm{A}_{10}$ & 1.13 & 1.3 & 1.3 & 1.2 & 1.1 \\
\hline $\mathrm{A}_{12}$ & 1.71 & 1.8 & 1.8 & 1.7 & 1.8 \\
\hline $\mathrm{A}_{14}$ & 0.77 & 0.5 & 0.7 & 0.8 & 0.7 \\
\hline $\mathrm{A}_{15}$ & 1.09 & 0.8 & 0.9 & 0.9 & 0.8 \\
\hline $\mathrm{A}_{18}$ & 1.34 & 1.2 & 1.2 & 1.3 & 1.5 \\
\hline $\mathrm{A}_{20}$ & 0.36 & 0.4 & 0.4 & 0.3 & 0.4 \\
\hline $\mathrm{A}_{22}$ & 0.97 & 1.2 & 1.3 & 1.0 & 1.0 \\
\hline $\mathrm{A}_{24}$ & 1.00 & 0.9 & 0.9 & 1.0 & 1.1 \\
\hline $\mathrm{A}_{26}$ & 1.03 & 1.0 & 0.9 & 1.0 & 1.0 \\
\hline $\mathrm{A}_{27}$ & 0.88 & 3.6 & 0.7 & 0.9 & 5.0 \\
\hline $\mathrm{A}_{28}$ & 0.55 & 0.1 & 0.1 & 0.1 & 0.1 \\
\hline $\mathrm{A}_{30}$ & 2.59 & 2.4 & 2.5 & 2.6 & 2.7 \\
\hline $\mathrm{A}_{31}$ & 0.84 & 1.1 & 1.0 & 0.9 & 0.9 \\
\hline $\mathrm{A}_{33}$ & 0.25 & 0.1 & 0.1 & 0.1 & 0.1 \\
\hline $\mathrm{A}_{35}$ & 2.86 & 2.7 & 2.9 & 2.8 & 3.0 \\
\hline $\mathrm{A}_{36}$ & 0.92 & 0.8 & 0.8 & 1.1 & 0.8 \\
\hline $\mathrm{A}_{38}$ & 0.67 & 0.1 & 0.1 & 0.1 & 0.1 \\
\hline $\mathrm{A}_{40}$ & 3.06 & 2.8 & 3.0 & 3.0 & 3.2 \\
\hline $\mathrm{A}_{41}$ & 1.04 & 1.3 & 1.2 & 1.1 & 1.1 \\
\hline $\mathrm{A}_{43}$ & 0.10 & 0.2 & 0.1 & 0.1 & 0.1 \\
\hline $\mathrm{A}_{45}$ & 3.13 & 3.0 & 3.2 & 3.1 & 3.3 \\
\hline $\mathrm{A}_{46}$ & 1.12 & 1.2 & 1.1 & 1.1 & 1.1 \\
\hline $\mathrm{x}_{2}$ & 107.76 & 114 & 104 & 109.61 & 100.5396 \\
\hline $\mathrm{x}_{4}$ & 89.15 & 97 & 87 & 93.078 & 81.0279 \\
\hline $\mathrm{y}_{4}$ & 137.98 & 125 & 128 & 126.65 & 137.2003 \\
\hline$x_{6}$ & 66.75 & 76 & 70 & 70.752 & 63.8334 \\
\hline $\mathrm{y}_{6}$ & 254.47 & 261 & 259 & 246.32 & 254.1838 \\
\hline $\mathrm{x}_{8}$ & 57.38 & 69 & 62 & 56.172 & 56.1445 \\
\hline $\mathrm{y}_{8}$ & 342.16 & 316 & 326 & 356.26 & 327.9040 \\
\hline $\mathrm{x}_{10}$ & 49.85 & 56 & 53 & 48.498 & 48.2708 \\
\hline $\mathrm{y}_{10}$ & 417.17 & 414 & 412 & 436.37 & 407.5132 \\
\hline$x_{12}$ & 44.66 & 50 & 47 & 42.37 & 42.4458 \\
\hline$y_{12}$ & 475.35 & 463 & 486 & 490.66 & 468.8267 \\
\hline $\mathrm{x}_{14}$ & 41.09 & 54 & 45 & 41.61 & 45.8692 \\
\hline $\mathrm{y}_{14}$ & 513.15 & 524 & 504 & 521.04 & 515.2907 \\
\hline $\mathrm{x}_{20}$ & 17.90 & 1.0 & 2.0 & 1.4026 & 0.0010 \\
\hline $\mathrm{y}_{20}$ & 597.92 & 587 & 584 & 597.36 & 586.9443 \\
\hline$x_{21}$ & 93.54 & 99 & 89 & 95.312 & 80.7351 \\
\hline $\mathrm{y}_{21}$ & 623.94 & 631 & 637 & 625.99 & 621.5769 \\
\hline Weight (lb) & 1900 & 1925.79 & 1871.7 & 1871.7 & 1869.876 \\
\hline No. of analyses & & 100,000 & N/A & 187,488 & 22,020 \\
\hline
\end{tabular}




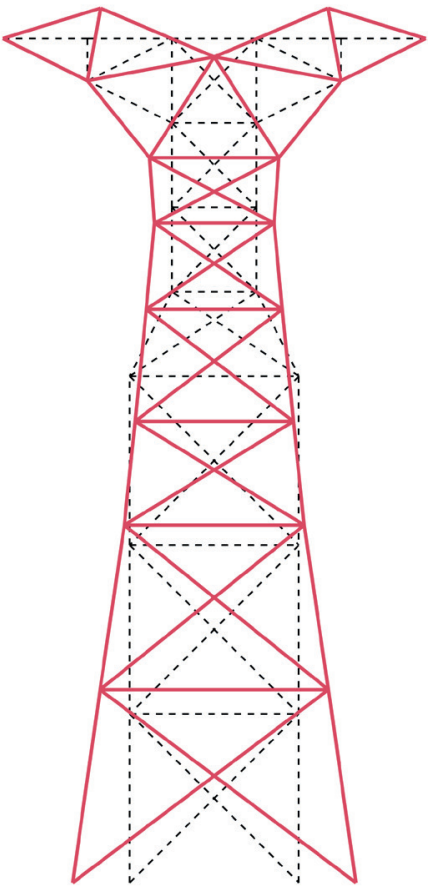

Fig. 11 Comparison of optimized layout for the 47-bar planar truss

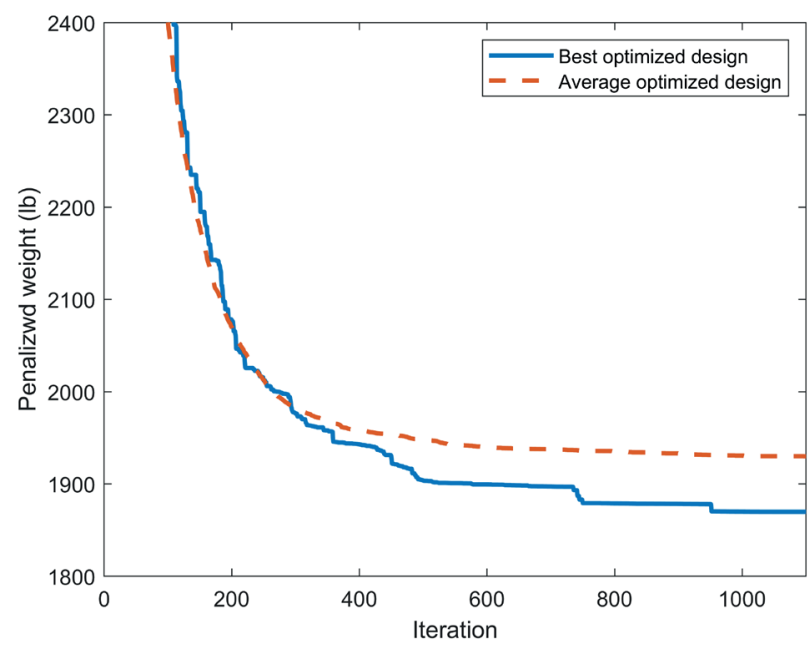

Fig. 12 Convergence histories of the optimization for the 47-bar planar truss

Massoudi [33] for size optimization with one single load case and Kaveh and Zaerreza [23] added 11 load cases to the basic load case as indicated in Table 9.

In this paper layout variables are added to this problem and all nodes are considered to be free to move in all direction. Nodes 1, 2, 11, 20, 29 are fixed and 62, 63, 64, 65 are fixed in the z-direction. Nodal coordinate, grouping members and end nodes of the members are available in [33]. The optimization problem includes 72 design variables containing 28 continuous sizing variables for the crosssection areas and 44 continuous layout variables for nodal coordinate. The modulus of elasticity is $2 \times 10^{8} \mathrm{kN} / \mathrm{m}^{2}$ and

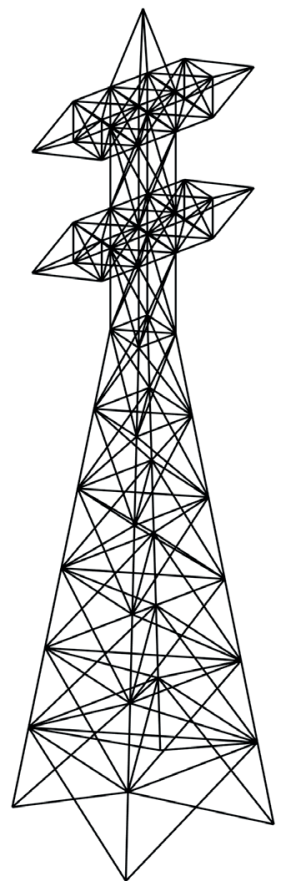

Fig. 13 Schematic of the 272-bar transmission tower

all members are subjected to stress limitation of \pm 275000 $\mathrm{kN} / \mathrm{m}^{2}$, Euler buckling stresses for compression members (the buckling strength of the ith element is set to $4 E A / L^{2}$ ) and displacement of nodes 1, 2, 11, 20, 29 are limited to $20 \mathrm{~mm}$ in Z-direction and to $100 \mathrm{~mm}$ in $\mathrm{X}$ - direction and $\mathrm{Y}$ - direction. Optimization variables of truss are given in Table 10.

Optimum volume found by SSOA is presented in Table 11. Optimum volume obtained by Kaveh and Zaerreza [23] without configuration variables has been 1168200.624, that is 36.93 percent more that value obtained by the present work. This indicates that optimization processes of this structure need configuration variables. Maximum stresses ratio is 0.89 which has happened in load Case 1 in element 263, and average volume and standard deviation for 30 independent runs are $764061.589 \mathrm{~cm}^{3}$ and $15485.12 \mathrm{~cm}^{3}$, respictively. Displacements for nodes 1, 2, 11, 20, 29 are shown in Fig. 14. Optimum layout found by SSOA is shown in Fig. 15. The convergence curves for the best result and the mean performance of 30 independent runs for the 272bar transmission tower are illustrated in Fig. 16.

\section{Conclusions}

In this paper, the capability of the new meta-heuristic algorithm so-called Shuffled Shepherd Optimization algorithm in layout optimization of structure is investigated. SSOA is a multi-community algorithm that mimics the shepherd behavior in nature. 
Table 9 Loading condition for the 272-bar transmission tower

\begin{tabular}{|c|c|c|c|c|c|c|c|}
\hline \multirow{2}{*}{ Case } & \multirow{2}{*}{ Force direction } & \multicolumn{6}{|c|}{ Nodes } \\
\hline & & 1 & 2 & 11 & 20 & 29 & Other free nodes \\
\hline \multirow{3}{*}{1} & $F_{x}(\mathrm{kN})$ & 20 & 20 & 20 & 20 & 20 & 5 \\
\hline & $F_{y}(\mathrm{kN})$ & 20 & 20 & 20 & 20 & 20 & 5 \\
\hline & $F_{z}(\mathrm{kN})$ & -40 & -40 & -40 & -40 & -40 & 0 \\
\hline \multirow{3}{*}{2} & $F_{x}(\mathrm{kN})$ & 0 & 20 & 20 & 20 & 20 & 5 \\
\hline & $F_{y}(\mathrm{kN})$ & 0 & 20 & 20 & 20 & 20 & 5 \\
\hline & $F_{z}(\mathrm{kN})$ & 0 & -40 & -40 & -40 & -40 & 0 \\
\hline \multirow{3}{*}{3} & $F_{x}(\mathrm{kN})$ & 20 & 0 & 20 & 20 & 20 & 5 \\
\hline & $F_{y}(\mathrm{kN})$ & 20 & 0 & 20 & 20 & 20 & 5 \\
\hline & $F_{z}(\mathrm{kN})$ & -40 & 0 & -40 & -40 & -40 & 0 \\
\hline \multirow{3}{*}{4} & $F_{x}(\mathrm{kN})$ & 20 & 20 & 20 & 0 & 20 & 5 \\
\hline & $F_{y}(\mathrm{kN})$ & 20 & 20 & 20 & 0 & 20 & 5 \\
\hline & $F_{z}(\mathrm{kN})$ & -40 & -40 & -40 & 0 & -40 & 0 \\
\hline \multirow{3}{*}{5} & $F_{x}(\mathrm{kN})$ & 20 & 0 & 0 & 0 & 0 & 5 \\
\hline & $F_{y}(\mathrm{kN})$ & 20 & 0 & 0 & 0 & 0 & 5 \\
\hline & $F_{z}(\mathrm{kN})$ & -40 & 0 & 0 & 0 & 0 & 0 \\
\hline \multirow{3}{*}{6} & $F_{x}(\mathrm{kN})$ & 0 & 20 & 0 & 0 & 0 & 5 \\
\hline & $F_{y}(\mathrm{kN})$ & 0 & 20 & 0 & 0 & 0 & 5 \\
\hline & $F_{z}(\mathrm{kN})$ & 0 & -40 & 0 & 0 & 0 & 0 \\
\hline \multirow{3}{*}{7} & $F_{x}(\mathrm{kN})$ & 0 & 0 & 0 & 20 & 0 & 5 \\
\hline & $F_{y}(\mathrm{kN})$ & 0 & 0 & 0 & 20 & 0 & 5 \\
\hline & $F_{z}(\mathrm{kN})$ & 0 & 0 & 0 & -40 & 0 & 0 \\
\hline \multirow{3}{*}{8} & $F_{x}(\mathrm{kN})$ & 0 & 0 & 20 & 20 & 20 & 5 \\
\hline & $F_{y}(\mathrm{kN})$ & 0 & 0 & 20 & 20 & 20 & 5 \\
\hline & $F_{z}(\mathrm{kN})$ & 0 & 0 & -40 & -40 & -40 & 0 \\
\hline \multirow{3}{*}{9} & $F_{x}(\mathrm{kN})$ & 0 & 20 & 20 & 0 & 20 & 5 \\
\hline & $F_{y}(\mathrm{kN})$ & 0 & 20 & 20 & 0 & 20 & 5 \\
\hline & $F_{z}(\mathrm{kN})$ & 0 & -40 & -40 & 0 & -40 & 0 \\
\hline \multirow{3}{*}{10} & $F_{x}(\mathrm{kN})$ & 0 & 0 & 20 & 0 & 20 & 5 \\
\hline & $F_{y}(\mathrm{kN})$ & 0 & 0 & 20 & 0 & 20 & 5 \\
\hline & $F_{z}(\mathrm{kN})$ & 0 & 0 & -40 & 0 & -40 & 0 \\
\hline \multirow{3}{*}{11} & $F_{x}(\mathrm{kN})$ & 0 & 0 & 0 & 20 & 20 & 5 \\
\hline & $F_{y}(\mathrm{kN})$ & 0 & 0 & 0 & 20 & 20 & 5 \\
\hline & $F_{z}(\mathrm{kN})$ & 0 & 0 & 0 & -40 & -40 & 0 \\
\hline \multirow{3}{*}{12} & $F_{x}(\mathrm{kN})$ & 0 & 0 & 20 & 20 & 0 & 5 \\
\hline & $F_{y}(\mathrm{kN})$ & 0 & 0 & 20 & 20 & 0 & 5 \\
\hline & $F_{z}(\mathrm{kN})$ & 0 & 0 & -40 & -40 & 0 & 0 \\
\hline
\end{tabular}

In order to demonstrate the ability of the SSOA in layout optimization problems, four classic layout optimization problems (consisting of the optimization of 15-bar planar truss,18-bar planar truss, 25-bar spatial truss and 47-bar planar truss) and one large scale problem (optimization of 272-bar transmission tower) are performed by the SSOA. For the 15-bar planer truss, the solution found by SSOA is only $0.3463 \mathrm{lb}$ more than the best solution found by other method but with smaller number of analyses among the others. In the 18-bar planar truss best solution is found by SSOA which is only 0.1 percent more than other method. In the 25-bar spatial truss and in 47-bar planar truss SSOA has found best solution with less number of analyses among the others and the result of 272-bar spatial truss shows that this problem needs configuration variables for improving the optimal solution. In SSOA both worst and 
Table 10 Simulation data for the 272-bar transmission tower

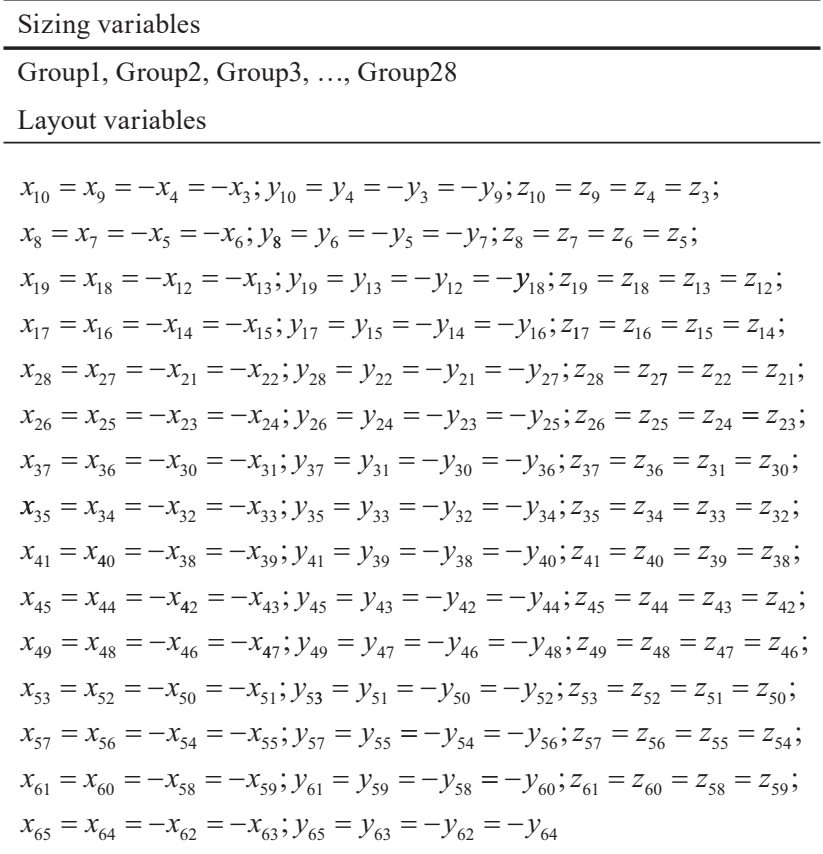

Layout variables bounds

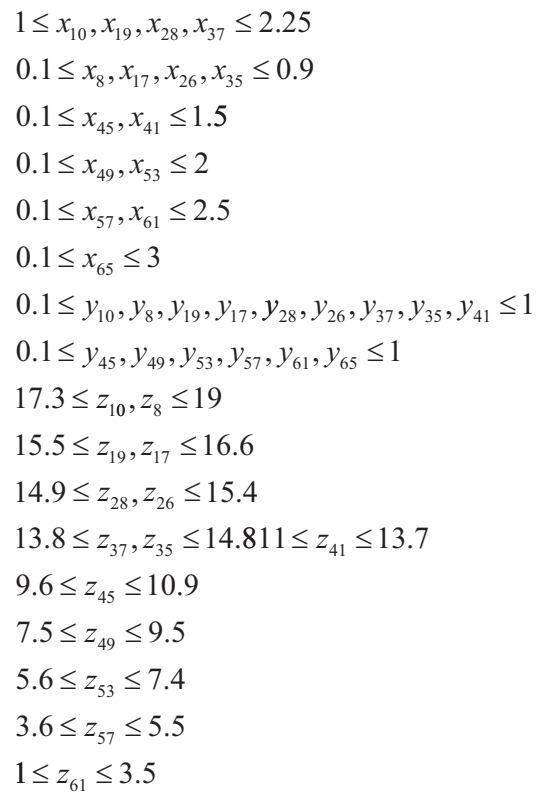

Possible sizing variables

$1000 \mathrm{~mm}^{2} \leq$ Group1, Group2, Group3, ..., Group28 $\leq 16.000 \mathrm{~mm}^{2}$ Young modulus $E=2 \times 108\left(\mathrm{KN} / \mathrm{m}^{2}\right)$

better agents have role in optimization process and results of the present study show that considering the worst agents in the optimization process can improve the performance of the algorithm and leads to better design.

\section{Compliance with ethical standards}

Conflict of interest: No potential conflict of interest was reported by the authors.
Table 11 Optimum design cross-section for the 272-bar transmission tower

\begin{tabular}{|c|c|c|c|}
\hline $\begin{array}{l}\text { Design } \\
\text { variables }\end{array}$ & Present work & $\begin{array}{c}\text { Design } \\
\text { variables }\end{array}$ & Present work \\
\hline Group 1 & 1000.2 & $z_{19}$ & 16.1015 \\
\hline Group 2 & 1000.0 & $x_{17}$ & 0.7327 \\
\hline Group 3 & 1000.2 & $y_{17}$ & 0.4548 \\
\hline Group 4 & 1000.0 & $z_{17}$ & 15.5185 \\
\hline Group 5 & 3412.4 & $x_{28}$ & 1.2562 \\
\hline Group 6 & 1000.4 & $y_{28}$ & 0.1003 \\
\hline Group 7 & 3786.5 & $z_{28}$ & 15.1170 \\
\hline Group 8 & 1003.0 & $x_{26}$ & 0.7572 \\
\hline Group 9 & 1008.1 & $y_{26}$ & 0.4915 \\
\hline Group 10 & 1003.2 & $z_{26}$ & 15.1625 \\
\hline Group 11 & 4498.3 & $x_{37}$ & 1.1038 \\
\hline Group 12 & 1001.0 & $y_{37}$ & 0.1902 \\
\hline Group 13 & 1000.1 & $z_{37}$ & 14.3021 \\
\hline Group 14 & 1000.4 & $x_{35}$ & 0.8821 \\
\hline Group 15 & 4615.9 & $y_{35}$ & 0.6002 \\
\hline Group 16 & 1000.3 & $z_{35}$ & 13.9793 \\
\hline Group 17 & 1000.0 & $x_{41}$ & 0.9384 \\
\hline Group 18 & 1005.6 & $y_{41}$ & 0.7835 \\
\hline Group 19 & 4826.0 & $z_{41}$ & 12.3261 \\
\hline Group 20 & 1000.4 & $x_{45}$ & 1.0161 \\
\hline Group 21 & 1001.7 & $y_{45}$ & 0.9049 \\
\hline Group 22 & 1001.4 & $z_{45}$ & 10.7022 \\
\hline Group 23 & 5092.8 & $x_{49}$ & 1.1052 \\
\hline Group 24 & 1000.8 & $y_{49}$ & 0.9440 \\
\hline Group 25 & 1008.1 & $z_{49}$ & 8.9221 \\
\hline Group 26 & 1007.6 & $x_{53}$ & 1.2439 \\
\hline Group 27 & 5072.8 & $y_{53}$ & 1.0765 \\
\hline Group 28 & 1000.8 & $z_{53}$ & 7.1762 \\
\hline$x_{10}$ & 1.0311 & $x_{57}$ & 1.5098 \\
\hline$y_{10}$ & 0.1003 & $y_{57}$ & 1.2954 \\
\hline$z_{10}$ & 17.3610 & $z_{57}$ & 4.9926 \\
\hline$x_{8}$ & 0.2283 & $x_{61}$ & 1.9012 \\
\hline$y_{8}$ & 0.4300 & $y_{61}$ & 1.6430 \\
\hline$y_{8}$ & 17.30005 & $z_{61}$ & 2.4470 \\
\hline$x_{19}$ & 1.0000 & $x_{65}$ & 2.3101 \\
\hline$y_{19}$ & 0.2649 & $y_{65}$ & 1.9996 \\
\hline Volume $\left(\mathrm{cm}^{3}\right)$ & & & 736814.944 \\
\hline $\begin{array}{l}\text { No. of } \\
\text { analyses }\end{array}$ & & & 51,030 \\
\hline
\end{tabular}



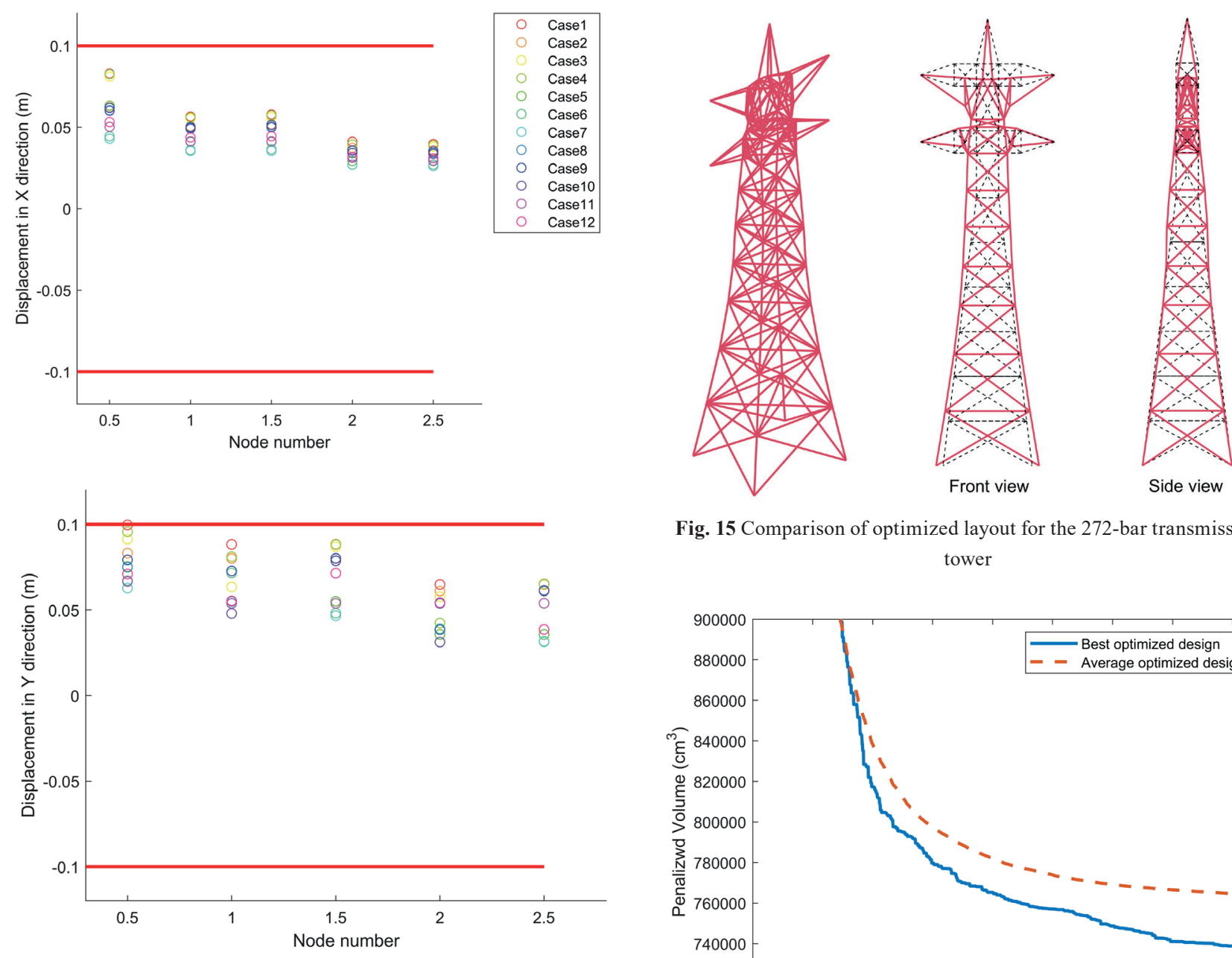

Fig. 15 Comparison of optimized layout for the 272-bar transmission tower

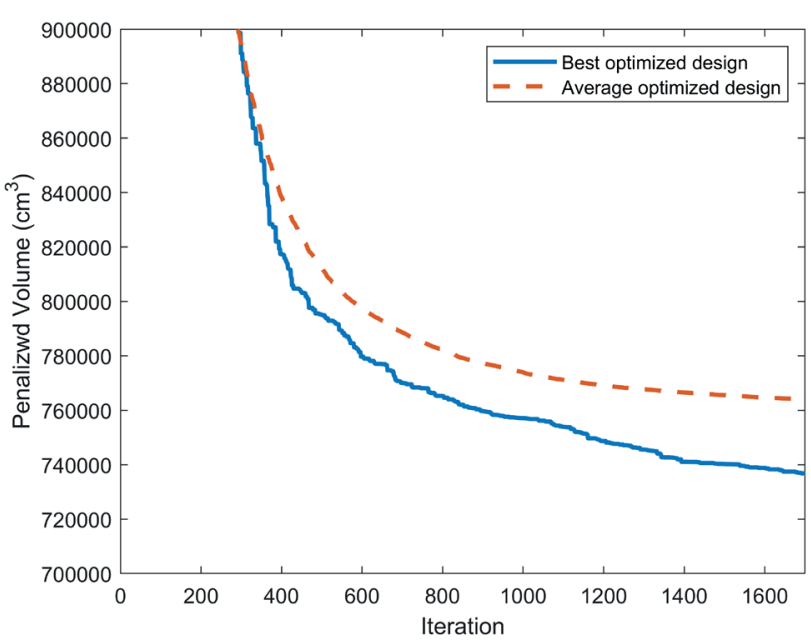

Fig. 16 Convergence histories of the optimization for the 272-bar transmission tower

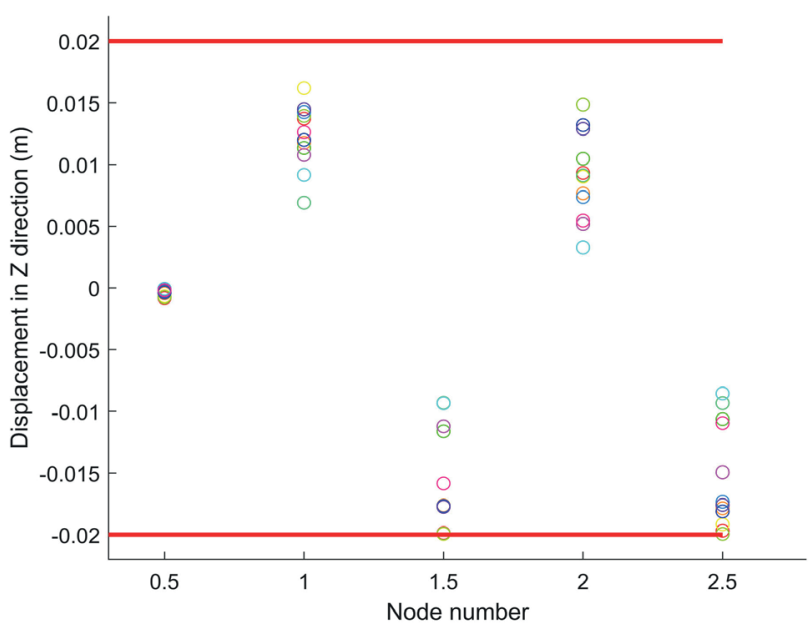

Fig. 14 Compression of allowable and existing displacements for the 272-bar transmission tower 


\section{References}

[1] Wu, S.-J., Chow, P.-T. "Integrated discrete and configuration optimization of trusses using genetic algorithms", Computers \& Structures, 55(4), pp. 695-702, 1995.

https://doi.org/10.1016/0045-7949(94)00426-4

[2] Hasançebi, O., Erbatur, F. "Layout optimization of trusses using improved GA methodologies", Acta Mechanica, 146, pp. 87-107, 2001.

https://doi.org/10.1007/BF01178797

[3] Kaveh, A., Khayatazad, M. "Ray optimization for size and shape optimization of truss structures", Computers \& Structures, 117, pp. 82-94, 2013.

https://doi.org/10.1016/j.compstruc.2012.12.010

[4] Kaveh, A., Laknejadi, K. "A hybrid evolutionary graph-based multi-objective algorithm for layout optimization of truss structures", Acta Mechanica, 224, pp. 343-364, 2013.

https://doi.org/10.1007/s00707-012-0754-5

[5] Kaveh, A., Zolghadr, A. "Democratic PSO for truss layout and size optimization with frequency constraints", Computers \& Structures, 130, pp. 10-21, 2014.

https://doi.org/10.1016/j.compstruc.2013.09.002

[6] Kaveh, A., Bakhshpoori, T., Afshari, E. "Hybrid PSO and SSO algorithm for truss layout and size optimization considering dynamic constraints", Structural Engineering and Mechanics, 54(3), pp. 453474,2015 .

https://doi.org/10.12989/sem.2015.54.3.453

[7] Kaveh, A., Ilchi Ghazaan, M. "Layout and size optimization of trusses with natural frequency constraints using improved ray optimization algorithm", Iranian Journal of Science and Technology Transactions of Civil Engineering, 39(C2+), pp. 395-408, 2015.

[8] Kaveh, A., Mahjoubi, S. "Hypotrochoid spiral optimization approach for sizing and layout optimization of truss structures with multiple frequency constraints", Engineering with Computers, 35(4), pp. 1443-1462, 2019.

https://doi.org/10.1007/s00366-018-0675-6

[9] Kazemzadeh Azad, S., Bybordiani, M., Kazemzadeh Azad, S., Jawad, F. K. J. "Simultaneous size and geometry optimization of steel trusses under dynamic excitations", Structural and Multidisciplinary Optimization, 58, pp. 2545-2563, 2018.

https://doi.org/10.1007/s00158-018-2039-7

[10] Kaveh, A., Hoseini Vaez, S. R., Hosseini, P., Ezzati, E. "Layout optimization of planar braced frames using modified dolphin monitoring operator", Periodica Polytechnica Civil Engineering, 62(3), pp. 717-731, 2018.

https://doi.org/10.3311/PPci.11654

[11] Kaveh, A. "Advances in Metaheuristic Algorithms for Optimal Design of Structures", 2nd ed., Springer, Cham, Switzerland, 2017. https://doi.org/10.1007/978-3-319-05549-7

[12] Kaveh, A. "Applications of Metaheuristic Optimization Algorithms in Civil Engineering", Springer, Cham, Switzerland, 2017. https://doi.org/10.1007/978-3-319-48012-1

[13] Kennedy, J., Eberhart, R. "Particle swarm optimization", presented at Proceedings of ICNN'95 - International Conference on Neural Networks, Perth, Australia, Nov, 27-Dec, 1, 1995. http://doi.org/10.1109/ICNN.1995.488968
[14] Yang, X.-S., Hossein Gandomi, A. "Bat algorithm: a novel approach for global engineering optimization", Engineering Computations, 29(5), pp. 464-483, 2012. https://doi.org/10.1108/02644401211235834

[15] Gandomi, A. H., Yang, X.-S., Alavi, A. H. "Cuckoo search algorithm: a metaheuristic approach to solve structural optimization problems", Engineering with Computers, 29(1), pp. 17-35, 2013. https://doi.org/10.1007/s00366-011-0241-y

[16] Mirjalili, S., Gandomi, A. H., Mirjalili, S. Z., Saremi, S., Faris, H., Mirjalili, S. M. "Salp Swarm Algorithm: A bio-inspired optimizer for engineering design problems", Advances in Engineering Software, 114, pp. 163-191, 2017. https://doi.org/10.1016/j.advengsoft.2017.07.002

[17] Hasançebi, O., Kazemzadeh Azad, S. "Adaptive dimensional search: a new metaheuristic algorithm for discrete truss sizing optimization", Computers \& Structures, 154, pp. 1-16, 2015. https://doi.org/10.1016/j.compstruc.2015.03.014

[18] Kaveh, A., Ilchi Ghazaan, M., Bakhshpoori, T. "An improved ray optimization algorithm for design of truss structures", Periodica Polytechnica Civil Engineering, 57(2), pp. 97-112, 2013. https://doi.org/10.3311/PPci.7166

[19] Duan, Q. Y., Gupta, V. K., Sorooshian, S. "Shuffled complex evolution approach for effective and efficient global minimization", Journal of Optimization Theory and Applications, 76, pp. 501-521, 1993.

https://doi.org/10.1007/BF00939380

[20] Eusuff, M., Lansey, K., Pasha, F. "Shuffled frog-leaping algorithm: a memetic meta-heuristic for discrete optimization", Engineering Optimization, 38(2), pp. 129-154, 2006. https://doi.org/10.1080/03052150500384759

[21] Jiang, Y., Hu, T., Huang, C., Wu, X. "An improved particle swarm optimization algorithm", Applied Mathematics and Computation, 193(1), pp. 231-239, 2007. https://doi.org/10.1016/j.amc.2007.03.047

[22] Sharma, T. K., Pant, M. "Shuffled artificial bee colony algorithm", Soft Computing, 21, pp. 6085-6104, 2017. https://doi.org/10.1007/s00500-016-2166-2

[23] Kaveh, A., Zaerreza, A. "Shuffled shepherd optimization method: A new Meta-heuristic algorithm", Engineering Computations, Published online, 2020. https://doi.org/10.1108/EC-10-2019-0481

[24] Kazemzadeh Azad, S., Kazemzadeh Azad, S., Jayant Kulkarni, A. "Structural optimization using a mutation-based genetic algorithm", International Journal of Ptimization in Civil Engineering, 2(1), pp. 81-101, 2012. [online] Available at: http://ijoce.iust.ac.ir/article-180-en.pdf [Accessed: 10 February 2020]

[25] Tang, W., Tong, L., Gu, Y. "Improved genetic algorithm for design optimization of truss structures with sizing, shape and topology variables", International Journal for Numerical Methods in Engineering, 62(13), pp. 1737-1762, 2005. https://doi.org/10.1002/nme.1244

[26] Rahami, H., Kaveh, A., Gholipour, Y. "Sizing, geometry and topology optimization of trusses via force method and genetic algorithm", Engineering Structures, 30(9), pp. 2360-2369, 2008. https://doi.org/10.1016/j.engstruct.2008.01.012 
[27] Miguel, L. F. F., Lopez, R. H., Miguel, L. F. F. "Multimodal size, shape, and topology optimisation of truss structures using the Firefly algorithm", Advances in Engineering Software, 56, pp. 23-37, 2013. https://doi.org/10.1016/j.advengsoft.2012.11.006

[28] Ho-Huu, V., Nguyen-Thoi, T., Nguyen-Thoi, M. H., Le-Anh, L. "An improved constrained differential evolution using discrete variables (D-ICDE) for layout optimization of truss structures", Expert Systems with Applications, 42(20), pp. 7057-7069, 2015. https://doi.org/10.1016/j.eswa.2015.04.072

[29] Hasançebi, O., Erbatur, F. "On efficient use of simulated annealing in complex structural optimization problems", Acta Mechanica, 157, pp. 27-50, 2002. https://doi.org/10.1007/BF01182153

[30] Kaveh, A., Kalatjari, V. "Size/geometry optimization of trusses by the force method and genetic algorithm", Journal of Applied Mathematics and Mechanics, 84(5), pp. 347-357, 2004.

https://doi.org/10.1002/zamm.200310106
[31] Salajegheh, E., Vanderplaats, G. N. "Optimum design of trusses with discrete sizing and shape variables", Structural Optimization, 6, pp. 79-85, 1993.

https://doi.org/10.1007/BF01743339

[32] Panagant, N., Bureerat, S. "Truss topology, shape and sizing optimization by fully stressed design based on hybrid grey wolf optimization and adaptive differential evolution", Engineering Optimization, 50(10), pp. 1645-1661, 2018.

https://doi.org/10.1080/0305215X.2017.1417400

[33] Kaveh, A., Massoudi, M. "Multi-objective optimization of structures using charged system search", Scientia Iranica, Transaction A, Civil Engineering, 21(6), pp. 1845-1860, 2014. [online] Available at: http://scientiairanica.sharif.edu/article_1775.html [Accessed: 10 February 2020] 